\title{
The Role of Micro and Small Business Enterprises in Linking Youth and Women in to Business: A Case Study in South Gondar Zone, Ethiopia
}

\author{
Dejen Debeb Asmare $^{1} \quad$ Alebel Weretaw Asaye $^{2}$ \\ 1.Department of Accounting And Finance, Faculty of Business And Economics, Debretabor University \\ 2.Department of Magment Faculty of Business And Economics, Debretabor University
}

\begin{abstract}
Micro and Small Enterprises (MSEs) occupy a prominent position in the development agenda of many developing countries like Ethiopia. MSEs are long recognized as important vehicles of economic diversification, employment creation, income generation and distribution, and poverty alleviation. Especially they brought marginalized groups (women and youth) in to development portfolio. The number of MSEs in Ethiopia is steadily growing but much more important than their number is their current status, stage and pace of development. Thus, the study aimed at assessing the role of MSEs inin linking youth and women in to business: which was addressed through examining the perception and participation of youth and women in the business. And the investigations also focused on assessment of the current trends, challenges and prospects of the sector and finally provide recommendations for policy implications of the businesses. To meet the objectives of the study, primary data were collected using questionnaire and focus group discussion with 384 respondents that were selected randomly from each stratum (woreda) enterprises of South Gondar Zone, Ethiopia. The study has covered almost all types of sectors that are identified by the zonal office. Following collection of necessary data, it were analyzed using descriptive and inferential statistical methods such as percentages, means, frequencies, ranges, standard deviations, Pearson's correlation and binary logistic regression model. The descriptive parts were also tested using Chi square and t-tests to check whether there is a significant relation between outcome and explanatory variables.
\end{abstract}

Keywords: Micro and Small Business Enterprises, Women, Youth.

DOI: $10.7176 /$ RJFA/10-23-05

Publication date: December $31^{\text {st }} 2019$

\section{INTRODUCTION}

\section{Background of the Study}

Micro and Small Business Enterprises (MSEs) are regarded as the driving forces of economic growth, job creation, and poverty reduction in developing countries in general and Ethiopia in particular. They have been the means through which accelerated economic growth and rapid industrialization have been achieved (Endalkachew, 2008).

In cities and towns of Ethiopia, MSEs and informal sector in general are the predominant income generating activities; they have a significant contribution to local economic development and used as the basic means of survival (Andualem, 2001). Empirical studies on micro and small-business development have shown that the rate of failure in developing countries is higher than in the developed world (Andualem, 2001).

Until recently, SMEs have not been a major area of focus in Ethiopia but nowadays the existing government has issued a national MSES development strategy for the promotion of MSEs in 1997 and established a wellconcerned institution for the sector by the Council of Ministers of Ethiopian Regulation No 33/1998 on April 3, 1998.

In spite of the enormous importance of the Micro and Small business Enterprises (MSEs) sectors to the national economy with regards to job creation and the alleviation of abject poverty among impoverished women in Ethiopia, the degree of recognition and strategic support provided to the sector is grossly inadequate. Three successive governments that were in power since 1960 have failed to improve the difficulty of women entrepreneurs in Ethiopia (Ethiopian Welfare Monitoring Unit, 2002).

The youth population, defined as those between 15 and 29 years old, is the most abundant asset in subSaharan Africa (SSA). In the region, the youth accounts for about 60 per cent of the population. Although some consider that the youth could be a potential demographic dividend for the region, youth employment is a challenge that confronts all the countries in sub-Saharan Africa.

Youth unemployment is a pressing issue in Ethiopia where almost two-thirds of the population is younger than 25 years. Over the past two decades, youth between the ages 15 and 29 increased by 7 per cent per year on average. In spite of the pressing youth employment challenge, youth issues were given only limited attention in the development policies of the country until recently. The current policy emphasis on the promotion of the private sector, expanding investment to improve the productivity of agriculture and introducing off-farm non- 
agricultural activities for the purpose of employment diversification in rural areas has resulted in some recovery and overall macroeconomic stability in the country (Berhanuetal, 2007). Like youths, women are the disadvantaged segment of the population that Micro and Small business Enterprises (MSEs) can link into business.

\section{The Problem Statement}

As part of the agricultural, industrial and service sectors, MSEs are increasingly becoming popular and important in the Ethiopian economy, as they would play a decisive role in contributing to employment generation, poverty reduction and the opening of wider distribution of wealth and opportunities. However, according to Stevenson \& Annette (2006), as cited by Endalkachew (2008), MSEs have faced a number of constraints, among others, lack of access to markets, finance, business information; lack of business premises; low ability to acquire skills and managerial expertise; low access to appropriate technology and poor access to quality business infrastructure. The sector is also known as an instrument in bringing about economic transition by effectively using the skill and talent of the people without requesting high-level training, much capital and sophisticated technology.

Although women entrepreneurs contribute significantly to the national economy in terms of job creation, skills development and the alleviation of abject poverty among men and women alike, the literature clearly shows that small and micro businesses enterprises operated by women entrepreneurs are not being provided with adequate strategic support in terms of policy, access to finance, tax assessment, skills development and managerial training, technological transfer and infrastructural development (Berhanuetal. 2007).

According to the census result (2007), the urban unemployment stands at 25\%. Recently, with around 50\% of the urban men between age 15 and 30 were unemployed. The policy for Micro and Small business Enterprises (MSEs) promulgated in 1998 serves as a guideline to all partners to stimulate the establishment of new enterprises enable the existing one to grow and become more competitive in capturing unemployed people.

But some reviewed empirical studies with regard to the sector focused on major challenges and constraints (Endalkachew, 2008; Weldegbriel, 2012; Workneh, 2007). There are many studies focused on problems and factors that hinder the growth of MSEs and the outcome of the program in aggregate forms. Ethiopian government has focused on creating micro and small business enterprises, based on their potential to create employment opportunities. Yet empirical studies fail to investigate the role of MSEs in linking youth and women in to business.

Hence, this research aiming at exploring the contributions of Micro and Small business Enterprises (MSEs) in linking youth and women in to businessin South Gondar Zone, Ethiopia. Moreover, it can be important in narrowing the research gap on such areas of the sector in the study area.

\section{Objectives of the Study \\ General Objective}

The general objective of the study is to assess the role of Micro and Small Business Enterprises in linking women and youth towards businesses cited in South Gondar Zone, Ethiopia.

\section{Specific Objectives}

The specific objectives of the study are:

- To examine the satisfaction level of the respondents towards engagement in Micro and Small Enterprises.

- To study the extent of youth's and women's participation in the business

- To identify the determinant factors of the business in linking the youth and women in to businesses.

\section{Conceptual Model}

There are a number of factors that affect Micro and Small business Enterprises (MSEs) in tying youth and women in to business. However, the following major determinant variables are the most important factors that are drawn after a thorough review of highly related literatures. 


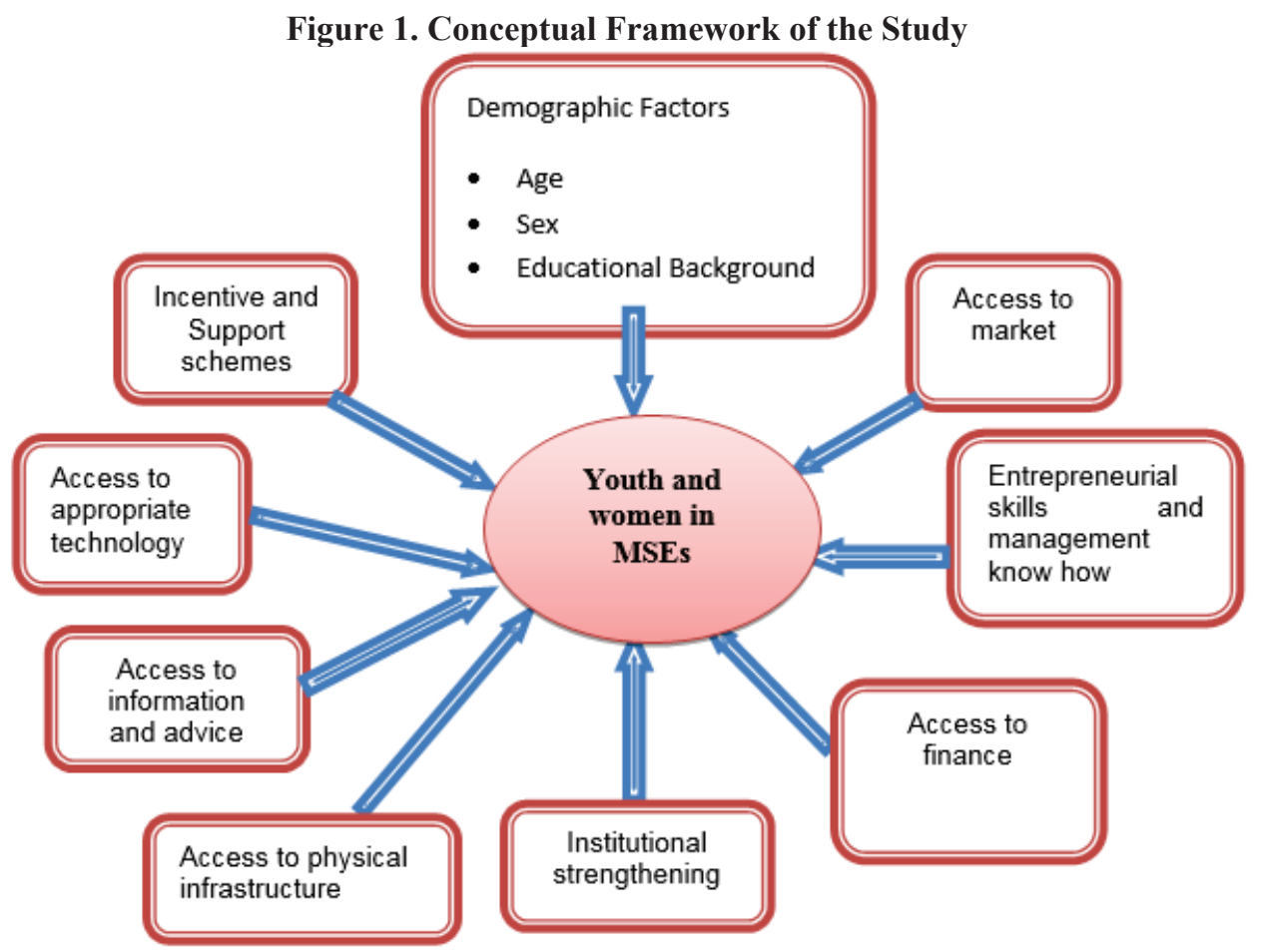

Source: Researcher's Own Compilation

\section{RESEARCH METHODOLOGY}

Background of the Study Area

Amhara national regional state is located in the north western and north central part of Ethiopia and divided into eleven provinces. Among the eleven administrative province of Amhara national regional state, South Gondar with 14 districts is the province where the study was conducted.

\section{Micro and Small business Enterprises in South Gondar Zone}

Micro and small business enterprises in South gander zone constitute sectors such as Construction, Manufacturing, Service, Trade and Urban Agriculture with a respective composition of 348,1523, 2186, 5479 and 61 and totaling 9597 (South Gondar Zone Micro and Small Business Support Service Bureau Base Line Data, 2016).

\section{Sampling Techniques and Sample Size}

The population for this study has been obtained from South Gondar Zone Micro and Small Enterprises Support Service Bureau dated on May 2016. The total number of MSEs in the study area is 9597 that have been grouped in to Construction, Manufacturing, Service, Trade and Urban Agriculture. Hence, Stratified-sampling technique (five sectors were formed in strata) was used to select the respondents proportionally.

\section{Sampling Techniques:}

The numbers of respondents that were questioned (sample size) were obtained using Yamane's (1967:886) formula, by determining from the total population. The formula states:

$$
n=\frac{\mathrm{N}}{1+N(e)^{2}}
$$

$$
\text { Sample Size }=\frac{9597}{1+9597(0.05)^{2}}=384
$$

Where: n-Sample size, N-population, e-Margin of error of 0.05 
Table 1: Sample Size Determination

\begin{tabular}{|c|c|c|c|c|}
\hline S.No. & Strata & Population & Proportion & Sample \\
\hline 1 & Construction & 348 & 3.62 & 14 \\
\hline 2 & Manufacturing & 1523 & 15.87 & 61 \\
\hline 3 & Service & 2186 & 22.78 & 87 \\
\hline 4 & Trade & 5479 & 57.09 & 219 \\
\hline 5 & Urban Agriculture & 61 & 0.64 & 3 \\
\hline & Total & 9597 & 100 & 384 \\
\hline
\end{tabular}

\section{Types of data and Methods of Data Collection}

\section{Source of Data}

Both primary and secondary sources of data were used for conducting the study. The primary data were obtained from sample respondents of MSEs. On the other hand, secondary data were extracted from the documents of the MSEs. Related web sites were also other sources of data for undertaking the research. In addition to above mentioned sources, the researcher referred books, journals, reports, study papers and published and unpublished documents to form theoretical framework of the study.

\section{Method of Data Collection}

In the processes of gathering data, different methods were utilized. As to primary data collection concerns, Questionnaire, focus group discussion and key informant interview methods were employed. Questionnaire was prepared to collect first-hand information from sample respondents. Finally, the secondary data relevant for this research work were collected from enterprises' reports and necessary documents of the zonal TVED Bureau.

Data types such as demographic, socio-economic, perception of respondents and contributions of MSEBs were gathered through questionnaire. FGDs were extended in line with the questionnaire but detail and reliable data were acquired and issues that need further analysis were acquainted with it. For gathering data regarding the perception of respondents on the contributions of MSEs, certain questions were asked to respondents by selected samples by adopting Likert scaling technique.

\section{Methods of Data Analysis and Interpretation}

Following the completion of data collection, the data were edited, coded and entered in to SPSS version 20, for analysis and interpretation purposes. The data were analyzed using both descriptive and inferential statistical methods. The descriptive statistics including percentages, means, frequencies, ranges and standard deviations were utilized to summarize and give condensed picture of the qualitative data. On the other hand, inferential statistical methods such as Pearson's correlation and binary logistic regression model were used to infer the quantitative analytical aspects. Specifically, the Pearson's correlation was implemented to make associational analysis on the perception level of respondents after the responses are scored with the categorization of Strongly Agree, Agree, Neutral, Disagree and Strongly Disagree perception levels. A model called Binary Logistic Regression on was extended for identifying determinant factors, which have significant impact on the linking of youth and women towards business opportunities. Furthermore, the model has been briefly described below.

\section{Specification of the logit model}

Models that include yes or no type dependent variable are called dichotomous or dummy variable regression models in which determinants of an event happening or not happening are identified. These include the linear probability function, linear discriminant function, logistic distribution function (logit), and normal distribution function (probit). These functions are used to approximate the mathematical relationship between explanatory variables and dependent dummy variable, which is always, assigned qualitative values (Pindyck and Rubinfeld, 1981).

The major point that distinguishes these functions from the linear regression model is that the outcome variable in this functions is binary or dichotomous (Hosmer and Lemeshow, 1989).

The logit and probit models are comparable, the main difference being that the logistic function has slightly flatter tails that is, the normal curve under logit function approaches the axes more quickly than in the case of probit function. Ignoring minor differences, Liao (1994), Gujarati, (1988) Pidyck and Rubinfeld (1981) pointed out that probit and logit models are quite similar. They usually generate predicted probabilities that are almost identical, though the logit model is preferred over the probit and it is simpler in estimation than the probit model (Aldrich and Nelson, 1984, Pindyck and Rubinfeld, 1981).

The modelthat was used to examine youth and women linkage to business:-

$\mathrm{Pi}=\mathrm{F}(\mathrm{Zi})$ 


$$
\begin{gathered}
Z i=B o+\sum_{i=1}^{n} B j X j i=\left\{\log \left(\frac{P}{1-P}\right)=Z i=\right. \\
\propto+B i X i+\cdots+B n X n
\end{gathered}
$$

(Engleman, 1981 and Gujarati, 1988)

Where, $\mathrm{Pi}=$ the probability that there is youth and women linkage to business, the binary variable, $\mathrm{Pi}=1$ for youth and women linkage to business and $\mathrm{Pi}=0$ for non-youth and women linkage to business.

$\mathrm{Zi}=$ Estimated variable for the $\mathrm{i}^{\text {th }}$ observation,

$\mathrm{F}=$ the functional relationship between $\mathrm{Pi}$ and $\mathrm{Zi} . \mathrm{i}=1,2 \ldots \mathrm{m}$ are observation on variables for youth and women linkage to business model, $\mathrm{m}$ being the sample size 384 .

$\mathrm{Xji}=$ the $\mathrm{j}^{\text {th }}$ explanatory variable for the $\mathrm{i}^{\text {th }}$ observation $=1,2$. ...n.

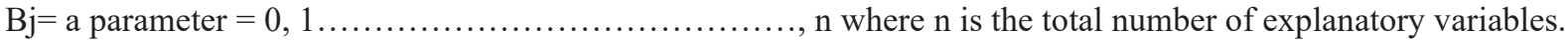
The logit model assumes the underlying index; $\mathrm{Zi}$ is a random variable that predicts the probability of youth and women linkage to business.

$P i$

$$
\begin{aligned}
& =\frac{1}{1+e^{-Z i}}-\frac{1}{1+e^{Z i}} \text {-_____ } \\
& 1-P i=\frac{}{1}
\end{aligned}
$$

If $\mathrm{Pi}$ is the probability of youth and women linkage to business, then (1-Pi) is otherwise, If the disturbance tem

$\mathrm{Ui}$ is taken in to account, the logit model becomes

$$
Z i=\mathrm{Bo}+\sum_{m=1}^{m} \mathrm{BiXi}
$$

This model will be used to analyze the data to be collected in this study. There are two measures that are often suggested to test the existence of Multicolliniarity. These are: variance inflation factor (VIF) for association among the continuous explanatory variables and contingency coefficients $(\mathrm{CC})$ for dummy variables. Thus variance inflation factor (VIF) is used to check Multicolliniarity of continuous variables. As $\mathrm{R}^{2}$ increase towards 1 , it is a collinearity of explanatory variables. The larger the value of VIF, the more troublesome or collinear is the variable $\mathrm{Xi}$

\section{RESULTS AND DISCUSSION \\ Descriptive statistics}

The descriptive statistics used to analyze the results of the quantitative data collected were used tools such as tables, percentages, mean, and frequency distribution and cross tabulation. In addition, the chi-square test was also employed.

\section{Demographic Characteristics of Respondents}

Distribution of the respondents by age group

It is the number of completed years of the respondent from the time of birth till the time of the survey conducted. The result indicated that $16.5 \%$ of the respondents were within the age group of $14-30$ years, $28.8 \%$ within the age group of $33-40$ years, $31.1 \%$ within the age group of $41-50$ years and the rest $21.6 \%$ were above 50 years old. It implies the majority of the respondents were within the age group of 33-40 years. As table 2 below shows, the average age of the respondents was 43.56 with a standard deviation of 11.569 . The minimum and maximum age of them was 20 and 55 respectively. Its T-value was 1.460 , which was significant at $10 \%$ probability level and has an association with engagement in micro and small business enterprises.

Table 2: Age of the respondents

\begin{tabular}{|l|l|r|r|}
\hline Variable & Statistics & Respondents(N)=384 & \multicolumn{1}{|c|}{ T- value } \\
\hline \multirow{4}{*}{ Age } & Mean & 43.56 & \\
\cline { 2 - 3 } & Standard deviation & 11.569 & 55 \\
\cline { 2 - 3 } & Maximum & 20 & $5.460 *$ \\
\cline { 2 - 3 } & Minimum & 20 & \\
\hline
\end{tabular}

Source: own survey, (2016). * represent level of significant at 10\%. 


\section{Distribution of respondents by sex and marital status}

As table 3 below indicates, it was found that from the total respondents about $55.2 \%$ were males and the rest $44.8 \%$ were females. This implies the majority of the respondents were male, but the engagement of females was lower. As far as their marital status is concerned, the respondents were categorized as single, married, divorced, and widowed. However, the result of the survey shows, the respondents have fallen under three categories only, as single/never married, married, and divorced. 66.41 percent were married, 28.64 percent were unmarried, and the rest 4.95 percent were divorced. This implies that the vast majority of respondents were unmarried.

Table 3: Respondents' sex and marital status

\begin{tabular}{|l|l|r|r|}
\hline Characteristics & Category & \multicolumn{2}{|c|}{ Respondents (N) = 384 } \\
\cline { 2 - 4 } & & Frequency & Percent \\
\hline Sex of the respondents & Male & 200 & 52.08 \\
\cline { 2 - 4 } & Female & 184 & 47.92 \\
\cline { 2 - 4 } & Total & 384 & 100 \\
\hline \multirow{2}{*}{ Marital status of the respondents } & Single & 255 & 66.41 \\
\cline { 2 - 4 } & Married & 110 & 28.64 \\
\cline { 2 - 4 } & Divorced & 19 & 4.95 \\
\cline { 2 - 4 } & Total & 384 & 100 \\
\hline
\end{tabular}

Source: own survey, (2016)

\section{Distribution of respondents by educational level}

The questionnaire included information on educational level of respondents to identify the skill of the respondent based on their level of education. Understanding the level of respondents' education helps in identifying and determining the development approaches to be followed (Aklilu.W, 2010). High level of human capital and research and development are positively associated with the performance of firms. They promote the growth of firms from low level of activities to large and better enterprises (Aklilu,W. 2010).

Educational level refers to the grades completed through formal schooling. It was considered that a member having longer years of formal schooling could have a better awareness and knowledge about MSEs. As to table 4 below, it was found that the majority of the respondents' education levels are from grade 9-12 (21.8 percent). Next to grade 9-12, the respondents with diploma level and degree level come second and third by having 39.8 and 16 percent respectively. It can be clearly observed from the figures that majority of the MSE business owners have less than diploma level of education which is 71.4 percent of the total respondents. It shows that education matters for the engagement of youth and women into business.

Table 4: Distribution of respondents by educational level

\begin{tabular}{|l|c|c|c|c|c|}
\hline \multirow{2}{*}{ Characteristics } & \multicolumn{3}{c|}{ Category } & \multicolumn{2}{c|}{$\begin{array}{c}\text { Total } \\
\text { Total }\end{array}$} \\
\cline { 2 - 7 } & $\begin{array}{l}\text { Read and } \\
\text { write }\end{array}$ & $9-12$ & 151 & 65 & 384 \\
\hline Frequency & 89 & 84 & 39.32 & 16 & 100 \\
\hline Percent & 23.3 & 21.8 & & \\
\hline
\end{tabular}

Source: own survey, (2016), $\quad * * *$ represent level of significant at $1 \%$.

Respondents' satisfaction as to their engagement in micro and small business enterprises

Table 5 shows, $39.06 \%$ of the respondents responded that they were highly satisfied, $39.84 \%$ satisfied, and the rest of $21.09 \%$ of the respondents responded that they were unsatisfied for their engagement in to business. The survey result indicates that the majority of the respondents were satisfied for their engagement in to business.

Table 5: Respondents' satisfaction as to their engagement in micro and small business enterprises

\begin{tabular}{|l|c|c|c|c|}
\hline \multirow{2}{*}{ Characteristics } & Highly satisfied & Satisfied & Unsatisfied & Total \\
\cline { 2 - 5 } & Freq (\%) & Freq (\%) & Freq (\%) & N (\%) \\
\hline Getting Incentive And Support Schemes & $150(39.06)$ & $153(39.84)$ & $81(21.09)$ & $384(100)$ \\
\hline Getting Access To Finance & $3(0.07)$ & $123(32.03)$ & $258(67.18)$ & $384(100)$ \\
\hline Being Profitable In The Business & $103(26.82)$ & $23(5.89)$ & $258(67.18)$ & $384(100)$ \\
\hline
\end{tabular}

Source: own survey, (2016)

Extent of youth's and women's participation in the business

As one can understand from table, in the micro and small business enterprises capture youth and women in the study area. In manufacturing enterprises 1459 youth and 748 women have been engaged in doing business. In construction micro and small enterprises there were3589 youth and 1574 women have been engaged in doing business. In service micro and small enterprises there were 2065 youth and 1756 women have been engaged in 
doing business. business.

In service micro and small enterprises there were 4214 youth and 2468 women have been engaged in the

Table 6: Extent of youth's and women's participation in the business

\begin{tabular}{|c|c|c|c|c|}
\hline \multirow[t]{2}{*}{ Enterprises } & \multirow{2}{*}{$\begin{array}{l}\text { Total number } \\
\text { of enterprise }\end{array}$} & \multicolumn{3}{|c|}{ Engagement of youth and women } \\
\hline & & youth & women & Total \\
\hline 1. Manufacturing & 1523 & 1459 & 748 & 2207 \\
\hline 1.1 MetalıWood Work And Engineering & 229 & 305 & 39 & 344 \\
\hline 1.2.Textile and cloth & 788 & 851 & 329 & 1180 \\
\hline 1.3 Lather and Lather Products & 8 & 9 & 1 & 10 \\
\hline 1.4. Food And Beverage Processing & 222 & 134 & 201 & 335 \\
\hline 1.5 Agro Processing & 252 & 143 & 172 & 315 \\
\hline 1.6 Traditional Hand Craft and Jewelry Work & 21 & 16 & 4 & 20 \\
\hline 1.7 Others & 2 & 2 & 2 & 4 \\
\hline 2. Construction & 348 & 3589 & 1574 & 5163 \\
\hline 2.1. Coble Stone & 35 & 298 & 115 & 413 \\
\hline 2.2. Others & 312 & 3291 & 1459 & 4750 \\
\hline 3. Service & 2186 & 2065 & 1756 & 3821 \\
\hline 3.1 Municipality Service & 11 & 151 & 22 & 173 \\
\hline 3.2 Others & 2175 & 1914 & 1734 & 3648 \\
\hline 4. Urban Agriculture & 61 & 242 & 121 & 363 \\
\hline 5. Trade & 5479 & 4214 & 2468 & 6682 \\
\hline Total & 9597 & 11569 & 6667 & 18236 \\
\hline
\end{tabular}

Source: south Gondar zone TVET, (2016)

Results from Binary Logistic Regression Model Analysis

The logistic regration model estimation results and marginal effect were used to identify the factors that affect linkage of youth and women into business.It is important, especially for analyzing the dichotomous dependent variable; it focuses on the significance impact of each variable on the dependent variable, i.e., youth and women engagement into productive business; the probability of getting a 1(engagement) or a 0 (non-engagement).

Multicollinearity test between the independent variables were also conducted using the variance inflation factor (VIF). To handle the heteroscedasticity problem, the robust logit regressions were also conducted and presented. The results of VIF showed that there was no multicollinearity problems among the variables considered. As a rule of thumb, if the VIF of a variable exceeds 10, there is a multicollinearity problem. In this study, there is no value greater than 10 (see appendix1) and therefore no multicollinearity problem. Hetroscedasticity is a situation where the disturbance terms do not have constant variance. Since the presence of hetroscedasticity would result in inconsistent estimators, the model was then estimated with SPSS version 20 software and used robust standard error to eliminate hetroscedasticity problem.

\section{Determinant Factors ofthe Business in Linking Youth ad Women in to Businesses}

It is initially important to assess the overall significance of the model. This has been made by considering chisquare test at the given degree of freedom. As shown in table 4.1.below in the logit model, the chi-square test $\left(\chi^{2}\right)$ is showing a statistically significant result at 95 percent confidence level, p-values is less than 5 percent. Therefore, it is evident that the model is good to fit to the data than that of no model.

This indicated that the likelihood ratio test statistic exceeds the chi-square critical value with 10 degree of freedom. The result is significant at less than 0.01 probabilities indicating that the hypothesis that all the coefficients except the intercept are equal to zero is not tenable. Likewise, the log likelihood value was significant at $1 \%$ level of significance. On the other hand, it is important to identify the statistical significance of each explanatory variable. As shown in the table 7 below out of 19 independent variables regressed in the model 8 coefficients of the explanatory variables were found to be statistically significant at 95 percent confidence interval.

Age (AG): It is a continuous variable, defined as the age at the time of study measured in years. It is hypostasized that as age of the individuals' increases; he/she will acquires knowledge and experience about the benefits of Micro and Small business Enterprises (MSEs) and he/she will join MSEs. So, it is positively related to youth and women linkage into business. This independent variable significantly affects engagement of youth and women in to business at $1 \%$ significant level other thing held constant.

Educational background (EB): It is a categorical variable, which refers to the grades completed through formal schooling. It is assumed that one having longer years of formal schooling will have a better awareness and 
knowledge about the MSEs and in turn he/she will inclined his/her intention to engage in MSEs. It will be measured by the number of years of formal schooling that one has attained. This variable also was found to influence engagement of youth and women in to business.

Incentive and Support schemes (ISS): It is operationally defined as how frequently office bearers follow up the activities of MSEs, how their effort strengthens the linkage of youth and women in the business. Frequent discussion and consultation is expected to improve the linkage of youth and women in the business. It is a dummy variable which takes a value of 1 if there is frequent discussion and consultation by office bearers 0 otherwise. The study also reveals that for a unit change from 0 to 1 in (Incentive and Support schemes), the probability of being engagement of youth and women in to business increases by 2.52 percent at $10 \%$ significance level, being other factors held constant. Meaning that youth and women who have got sufficient and adequate Incentive and Support schemes have high possibility of being engaged in to business than others who did not.

Access to market (AM):It refers to availability of market or demand to the products/services of MSEs in the study area .It is assumed that access to market plays a significant role in promoting MSEs. As result, access to adequate market is expected to positively correlate with youth and women linkage into business. It is a dummy variable which takes a value of 1 if there is access to adequate market and 0 otherwise. The study also reveals that for a unit change from 0 to 1 in (access to market), the probability of engagement of youth and women in to business increases by 14.74 percent at $10 \%$ significance level, being other factors held constant. Meaning that youth and women who have got access to markethave high possibility of engagement in to business others who did not.

Institutional strengthening (IS):It is operationally defined as technical and material support given to MSEs. It is a dummy variable which takes a value of 1 technical and material support given to MSEs and 0 otherwise. The study also reveals that for a unit change from 0 to 1 in (Institutional strengthening), the probability of engagement in to business by 26.78 percent at $5 \%$ significance level, being other factors held constant. Meaning that youth and women who have got technical and material support from governmental and non-governmental organizations have high possibility ofengagementof youth and women in to business than others who did not.

Access to physical infrastructure (AIF):It refers to availability of physical infrastructure for MSEs in the study area. It is assumed that access to physical infrastructure plays a significant role in promoting MSEs. As result, access to adequate physical infrastructure is expected to positively correlate with youth and women linkage into business. It is a dummy variable which takes a value of 1 if there is access to adequate market and 0 otherwise. The study also reveals that for a unit change from 0 to 1 in (availability of physical infrastructure for MSEs), the probability of engagement of youth and women increases by 11.6 percent at $10 \%$ significance level, being other factors held constant. Meaning that engagement of youth and women who have got availability of physical infrastructure has high possibility of being engaged in to business than others who did not.

Access to information and advice (AIA):refers to availability of provision information and advisory service for managers/ owners of MSEs and the larger community since start up to the time of study. It is assumed that provision of information and advice by concerned bodies to managers/ owners of MSEs and the larger community would create awareness about MSEs to the larger community there by increases youth and women engagement in MSEs.Thisvariable also was found to influence engagementof youth and women in to businessthan others who did not and significantly at 5\% significance level keeping the other factors constant.

Access to appropriate technology (ATAT):It refers to availability of technology to the activities of MSEs in the study area. It is assumed that availability of technology to the activities of MSEs in the study area plays a significant role in promoting MSEs. As result, access to appropriate technology is expected to positively correlate with youth and women linkage into business. It is a dummy variable which takes a value of 1 if there is access to appropriate technology and 0 otherwise. Theoutput of logistic regression proves that thisvariable also was found to influence engagementof youth and women in to businessthan others who did not and significantly at 5\% significance level keeping the other factors constant. 
Table 7:Determinants of Youth and women engagement in Micro and small enterprises from Binary Logistic Regression Analysis

\begin{tabular}{|c|c|c|c|c|c|c|c|c|}
\hline \multirow[t]{2}{*}{ Explanatory Variables } & \multirow[t]{2}{*}{$\begin{array}{c}\text { Coeff } \\
(\beta)\end{array}$} & \multirow[t]{2}{*}{ S.E. } & \multirow[t]{2}{*}{ Wald } & \multirow[t]{2}{*}{ df } & \multirow[t]{2}{*}{ Sig. } & \multirow{2}{*}{$\begin{array}{c}\text { Odds } \\
\text { Ratio } \\
(\operatorname{Exp}(\boldsymbol{\beta}))\end{array}$} & \multicolumn{2}{|c|}{$\begin{array}{l}\text { 95.0\% C.I. for } \\
\operatorname{EXP(B)}\end{array}$} \\
\hline & & & & & & & Lower & Upper \\
\hline Constant & -7.780 & 5.001 & 2.420 & 1 & 0.120 & 0.000 & & \\
\hline Age & -1.268 & 0.867 & 2.139 & 1 & 0.144 & 0.281 & 0.051 & 1.539 \\
\hline $\begin{array}{l}\text { Education (Able to write } \\
\text { and read) }\end{array}$ & 3.151 & 3.405 & 0.856 & 1 & 0.355 & 23.356 & 0.030 & $1.847 \mathrm{E} 4$ \\
\hline Education (Elementary) & -1.884 & 3.349 & 0.316 & 1 & 0.574 & 0.152 & 0.000 & 107.820 \\
\hline Education (High school) & 1.387 & 3.128 & 0.197 & 1 & 0.657 & 4.005 & 0.009 & $1.843 \mathrm{E} 3$ \\
\hline Education (Diploma) & 5.501 & 1.583 & 12.068 & 1 & $0.001^{*}$ & 244.895 & 10.993 & $5.455 \mathrm{E} 3$ \\
\hline Education (Degree) & 10.105 & 4.533 & 4.969 & 1 & $0.026 * *$ & $2.446 \mathrm{E} 4$ & 3.388 & $1.766 \mathrm{E} 8$ \\
\hline $\begin{array}{l}\text { Incentive and Support } \\
\text { schemes }\end{array}$ & -2.525 & 0.985 & 6.573 & 1 & $0.010 * *$ & 0.080 & 0.012 & 0.552 \\
\hline Access to market & 1.474 & 0.675 & 4.761 & 1 & $0.029 * *$ & 4.365 & 1.162 & 16.399 \\
\hline $\begin{array}{l}\text { Entrepreneurial skills and } \\
\text { management know how }\end{array}$ & 10.7090 & 0.205 & 4.217 & 1 & $0.022 * *$ & 0.064 & 0.006 & 0.677 \\
\hline Access to finance & 2.092 & 0.790 & 7.021 & 1 & $0.008 *$ & 8.104 & 1.724 & 38.094 \\
\hline Institutional strengthening & 2.678 & 0.932 & 8.255 & 1 & $0.004^{*}$ & 14.559 & 2.343 & 90.487 \\
\hline $\begin{array}{l}\text { Access to physical } \\
\text { infrastructure }\end{array}$ & 11.604 & 0.825 & 3.779 & 1 & 0.052 & 0.201 & 0.040 & 1.013 \\
\hline $\begin{array}{l}\text { Access to information and } \\
\text { advice }\end{array}$ & 2.953 & 0.602 & 2.509 & 1 & $0.001 *$ & 0.386 & 0.119 & 0.254 \\
\hline $\begin{array}{l}\text { Access to appropriate } \\
\text { technology }\end{array}$ & -2.752 & 1.205 & 5.217 & 1 & $0.022 * *$ & 0.064 & 0.006 & 0.677 \\
\hline $\begin{array}{l}\text { Incentive and Support } \\
\text { schemes }\end{array}$ & 5.501 & 1.583 & 12.068 & 1 & $0.001 *$ & 244.895 & 10.993 & $5.455 \mathrm{E} 3$ \\
\hline
\end{tabular}

Source: Field Survey, 2016

\section{Conclusions and recommendations}

The Micro and small enterprises sector is believed to be able to fill the gap that exist between poor and the rich in developing countries regarding income generation and, unemployment rate. Successful small businesses are the primary engines for economic development such as income growth and poverty reduction in many of the developing countries. These businesses can also build foundation for stable communities and gender equality (MELFED, 2004).

Micro and small enterprises are most effective but challenged enterprises; helpful in improving the economic lives of youth and women particularly through generating income, creating employment opportunities, improving productivity \& assets and asset building. They are among the major economic activities in the Amhara regional state next to agriculture (MOFED, 2002). Many people in the region are employed and get income by working in these organizations.

Micro and small business enterprises are hindered by problems of infrastructure, finance, technical \& managerial aspects and lack of knowledge about entrepreneurship.Considerable economic contributions made by micro and small business enterprises. But, there is still much more to be done.

This study focuses on Micro and small enterprises role in linking youth and women in to business in the case of south Gondar zone by reviewing five sectors. The sectors were construction, manufacturing, trade, agriculture and service. About 384 sample respondents were taken from MSEs. As a result, the findings of the study can be summarized as follows:

The result indicates that $16.5 \%$ of the respondents were within the age group of $14-30$ years, $28.8 \%$ within the age group of 33-40 years, $31.1 \%$ within the age group of $41-50$ years and the rest $21.6 \%$ were above 50 years old. It implies the majority of the respondents were within the age group of 33-40 years. The minimum and maximum age of them was 20 and 55 respectively. Its T-value was 1.460 , which was significant at $10 \%$ probability level and has an association with engagement of youth and women in micro and small business enterprises. Itwas found that from the total respondents about 55.2\% were males and the rest $44.8 \%$ were females. This implies the majority of the respondents were male, but the engagement of females was lower. 
As far as their marital status is concerned, the respondents were categorized as single, married, divorced, and widowed. However, the result of the survey shows, the respondents have fallen under three categories only, as single/never married, married, and divorced. 66.41 percent were married, 28.64 percent were unmarried, and the rest 4.95 percent were divorced. This implies that the vast majority of respondents were unmarried.

Itwas found that the majority of the respondents' education levels were from grade 9-12 (21.8 percent). Next to grade 9-12, the respondents with diploma level and degree level come second and third by having 39.8 and 16 percent respectively. It can be clearly observed from the figures that majority of the MSE business owners have less than diploma level of education which is 71.4 percent of the total respondents. It shows that education matters in the engagement of youth and women into business.

As to respondents' satisfaction in their engagement in micro and small business enterprises $39.06 \%$ of the respondents responded that they were highly satisfied, 39.84\% satisfied, and the rest of $21.09 \%$ of the respondents responded that they were unsatisfied for their engagement in to business. The survey result indicates that the majority of the respondents were satisfied for their engagement in to business.

As to the Extent of youth's and women's engagement in each of the five categories of the enterprises: 1459 youth and 748 women have been engaged in the manufacturing enterprise;3589 youth and 1574 women engaged in construction sector micro and small enterprises; 2065 youth and 1756 women also engaged in service micro and small enterprises.

The logistic regration result shows that out of 19 independent variables regressed in the model 8 coefficients of the explanatory variables were found to be statistically significant at 95 percent confidence interval. The variables were educational level, access to market;entrepreneurial skills and management know how, access to finance,institutional strengthening,access to physical infrastructure,access to information and advice and access to appropriate technology.

\section{Recommendations}

Based on the major findings mentioned in the analysis, a number of policy recommendations have been drawn with the view to improve the role of micro and small enterprises in linking youth and women into business.

$\checkmark$ Providing Access to credit: The support of MFIs and Banks should be encouraged through varying methods, such as widening the kind or range of collaterals, providing credit by making longer repayment, increase the amount of loan provided for group based lending.

$\checkmark$ Provide work place: Thus, government with support from donors could engage in constructing shades for MSEs to address the problem of work place, coupled with measures to encourage private investors to engage in construction of premises suitable for entrepreneurs. In this regard, the government should provide certain incentives for private investors such as tax relief for some time and availing of lease-free land, etc. Creating work premises would benefit MSEs in reducing costs of high rent, reducing displacement, reducing closures of an enterprise. In addition, if MSEs have a constant work place, they can draw long year strategic plans regarding expansion of the business.

$\checkmark$ Marketing Assistance: With regard to marketing support, the following measures need to encourage by the government.

- $\quad$ Linking MSEs with medium and large firms to serve as market outlets.

- Provision of training on quality improvement and cost reduction modalities.

- Provision of information on market opportunities \& appropriate/improved technologies.

- Construction of display centers and provision of advertising support.

- Establishment of market information centers.

$\checkmark$ Business Development Services: In this regard support agencies need to tailor their training and an advisory service to meet the specific needs and situation of MSEs. Support organizations can also play facilitating roles by referring and linking MSEs to other organizations for special skills training. The managerial trainings can be how to record, how to do the debit and asset etc. The technical training should be given depending on the type of the business and sector so that it will help MSEs to supply goods and services in quality and quantity thereby get demand for their products. Both these trainings should be given to new as well as existing MSEs.

$\checkmark$ Improving Educational System: The zonal trade and industry should participate in designing and implementing good educational policy that can help youngsters to be innovators and self-employed. The unemployment rate and low income among youth and women can be reduced highly if there is a good educational policy, which encourages creating job and high productivity there by increases income.

$\checkmark$ Carrying with Follow Up and Evaluation and Provide Integrated support: thelocal administration has to be integrated in any supports provided to MSEsin order to enhance their capacity and ensure sustainability of the enterprise.

$\checkmark \quad$ Capacity Building to Bureaus: The supporting agencies and organizations such as, government and donors should be Strengthened, bureau of trade and industry at regional and zone level, local administration through 
providing the necessary facilities.

\section{References}

Andualem T. (2001). Ethio-German Micro Enterprise, 'Problem Identification in Three Metropolitan Cities', Chamber of Commerce, Addis Ababa.

Arinaitwe, J. K. (2006), Factors Constraining the Growth and Survival of Small Scale Businesses, A Developing Countries Analysis, Journal of American Academy of Business, Cambridge, 8(2), 167-178.

Berhanu. D, Abraham. T,\& Hannah Van Der Berg. D. (2007).Characteristics and determinants of youth unemployment, underemployment and inadequate employment in Ethiopia.Employment Policy Unit. Retrieved January, 2008 from www.ilo.org/public

Central Statistical Agency (2006), Report on Large and Medium Scale manufacturing and Electricity Industries Survey, Addis Ababa, Ethiopia.

Endalkachew M. (2008), Underlying Causes of Micro and Small Business Failures in Addis Ketema Sub City: A Case Study Addis Ababa University, Ethiopia.

Federal Democratic Republic of Ethiopia Population Census Commission (2007), Addis Ababa, Ethiopia.

Federal Micro and Small Enterprise Development Agency (1997)."Micro and Small Enterprise Development policy and Strategy", Addis Ababa

Federal Micro and Small Enterprise Development Agency (2010)."Micro and Small Enterprise Development policy and Strategy", Addis Ababa

Hosmer, D. \&Lemeshow, S., 1989. Applied Logistic Regression.New York: John Wiley \& Sons. Available at: books.google.com > Mathematics > Probability \& Statistics > General [Accessed on March, 2017].

Liedholm, C. and Mead, D. (1990).Small Enterprises and Economic Development. The Dynamics of Micro and Small Enterprises, London/New York, Rutledge

Monk, R. (2000), Why small businesses fail?(Electronic version), CMA Management.

MuluGebreeyesus(2007), Growth of Micro-Enterprises: Empirical evidence from Ethiopia, Ethiopian Development Research Institute (EDRI)

Solomon Worku (2004), Socio Economic Determinants of Growth of Small Manufacturing Enterprises in Addis Ababa, Addis Ababa University, Ethiopia.

Yamane, T., (1967): Statistics: An Introductory Analysis; Harber and Row, New York.

Zewde (2002) Jobs, Gender and Small Enterprises in Africa.Women Entrepreneurs in Ethiopia Preliminary Report. Addis Ababa, SEDP-ILO.

Zeytu, G., (nd).Knowledge, Attitude towards Practicing of Voluntary HIV Counseling and Testing and the Determinants of VCT Uptake: A Case Study in Debre-birhan Teachers Training College. Ethiopia: Debre$\begin{array}{lll}\text { birhan } & \text { Teachers } & \text { Training College. } \\ \text { http://www.statssa.gov.za/ycs/SpeakerPresentations/Parthenon/Session }\end{array}$ VIE/Session\%20V20Southall_plenary/Zeytu\%20Gashaw\%20new.pdf [Accessed on May, 2016]. 